\title{
A FIRST INVESTIGATION INTO THE IMPACT OF VERY LARGE-SCALE OFFSHORE SAND MINING ALONG THE DUTCH COAST
}

\author{
Jebbe van der Werf ${ }^{1}$, Alessio Giardino ${ }^{1}$, Jan Mulder $^{1}$ and Ad Stolk $^{2}$
}

\begin{abstract}
This paper investigates the impact of very large-scale offshore sand mining along the Dutch coast on waves, currents, sand transport rates and morphology. To this end, we simulate different extreme sand extraction trench geometries (depths between 1 and $17 \mathrm{~m}$, volumes between 10 and $63 \times 10^{9} \mathrm{~m}^{3}$ ) with the process-based modelling system Delft3D. The simulations show that the waves become $0-20 \%$ higher, currents change with $0-0.3 \mathrm{~m} / \mathrm{s}$ and transport rates with $10-80 \%$. In general, the trench has a negative effect on the sand balance of coastal sections, especially near the narrow part of the deepening. The estimated trench impact on dune erosion during normative storm conditions with a frequency of occurrence of $1 / 10,000 \mathrm{yr}$ is $5-10 \%$. The impact of the deepening is generally seen to increase with depth.
\end{abstract}

Keywords: dune erosion; marine sand extraction; morphological modelling; Netherlands Continental Shelf; sea level rise

\section{INTRODUCTION}

Currently, 25-30 million $\mathrm{m}^{3}$ of sand is mined yearly in the Dutch part of the North Sea. This sand is being used to nourish the coast to keep up with sea level rise and for infrastructural works. In The Netherlands, offshore sand mining mainly takes place between the established NAP $-20 \mathrm{~m}$ depth contour (NAP is a vertical datum close to mean sea level at the Dutch coast) and 12 sea miles (about $22 \mathrm{~km}$ ) from the coast. This sand demand could rise in the near future in light of a possible increase in sea level rise and the construction of large infrastructural works.

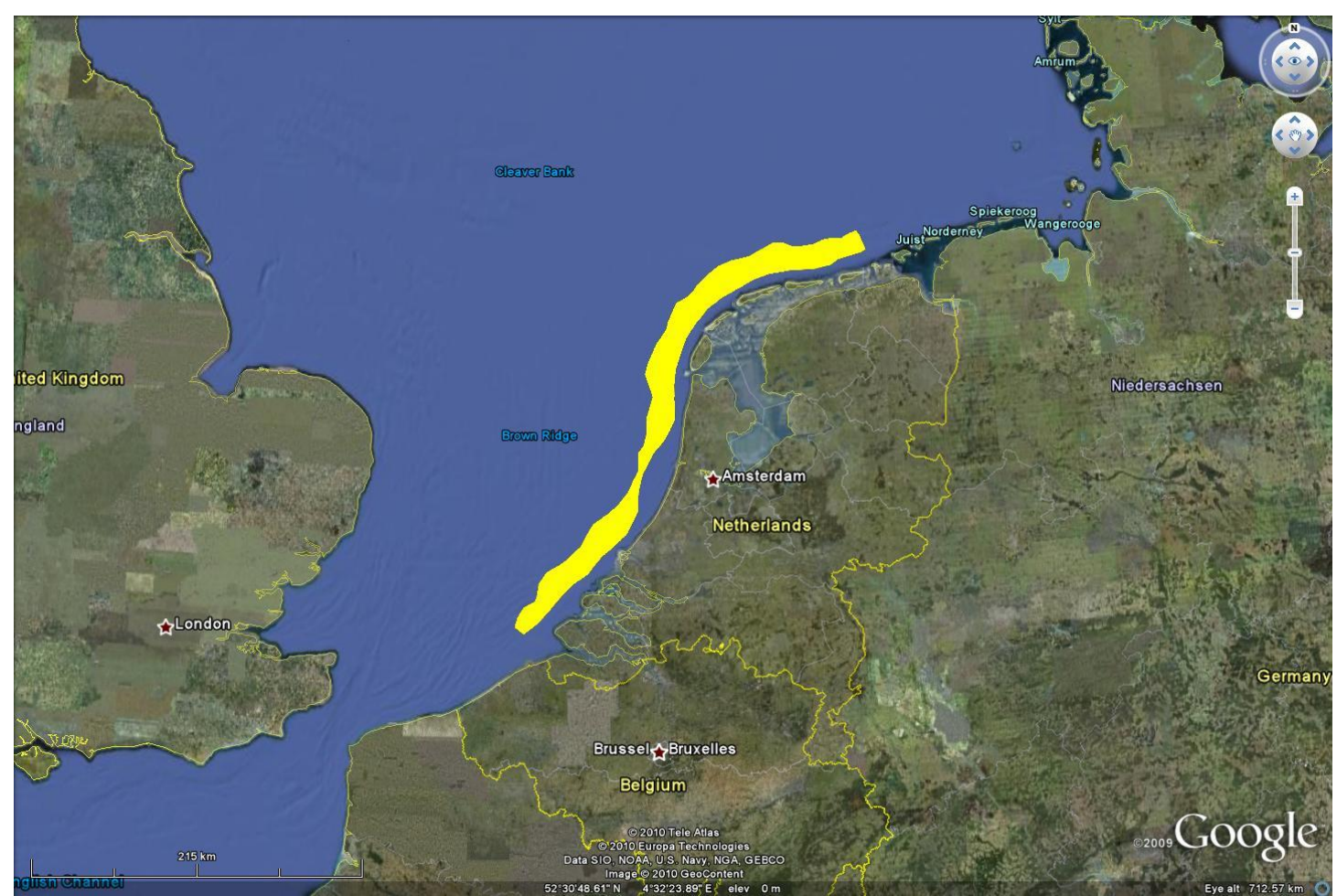

Figure 1. The area between the established NAP -20 m depth contour and 12 sea miles from the Dutch coast, which is exploited for offshore sand mining in The Netherlands.

To meet the potential increase in sand demand, it will be necessary to mine on a larger scale (deeper and wider) than current practice. If this mining will be carried out between the established

\footnotetext{
${ }^{1}$ Marine \& Coastal Systems, Deltares, P.O. Box 177, $2600 \mathrm{MH}$, Delft, The Netherlands

${ }^{2}$ Ministry of Transport, Public Works and Water Management, Rijkswaterstaat Noordzee, P.O. Box 5807, $2280 \mathrm{HV}$ Rijswijk, The Netherlands
} 
NAP -20 m depth contour and the 12 sea miles border, a deep trench could be created along the entire Dutch coast on the long run (centuries).

This would mean a large-scale intervention in a complex hydrodynamical (waves and tide), morphological and ecological system. The impact of such a trench is yet unknown since previous studies (e.g. Ribberink, 1989; Boers, 2005) focused on the (local) impact of mining by means of sand mining pits with much smaller dimensions than considered in this paper. In the near future, a sand mining strategy needs to be developed for the North Sea which include choices about mining locations and quantities. Such a strategy requires knowledge on the impact of very large-scale offshore sand mining along the Dutch coast.

To investigate the impact of very large-scale offshore sand mining, two modelling approaches can be followed: 1) idealized and 2) engineering models. Idealized process-based models are specifically designed to achieve insight in physical mechanisms. Typical properties are the schematizations of geometry and physics, attempting to retain only the essential features, processes and mechanisms, and the emphasis on (semi-)analytical solution techniques. As a result, idealized models are usually quick to run, thus allowing for extensive sensitivity analyses with respect to geometry and physics. This approach is followed by De Boer et al. (2011). This paper follows the alternative approach.

We simulate the impact of different very large-scale mining trenches on waves, currents, sand transport and morphology with the process-based modelling system Delft3D (see Lesser et al., 2004). Compared to idealized models, simulations require a larger computational effort, which makes it more difficult to conduct extensive sensitivity analyses and to obtain insight in physical mechanisms. However, engineering models - characterized by detailed model geometries and the inclusion of many physical processes - are more helpful in answering site-specific engineering questions.

This paper is organised as follows. First, we describe the model set-up and validation. Then we discuss the results from the model simulations, showing the impact of different sand extraction trenches on offshore and nearshore hydrodynamics, transport rates and morphology. Finally, we present the conclusions and recommendations.

\section{MODEL SET-UP}

\section{General}

We have set-up a depth-averaged two-dimensional horizontal (2DH) fully coupled wave (SWAN) -flow (Delft3D) model of the Dutch coast extending to about $50 \mathrm{~km}$ offshore: the so-called Netherlands Coastal Model (NCM). The model is morphostatic, which means that sand transport rates are computed but bed levels are not updated.

\section{Computational grids}

The computational grids of the wave and current model almost cover the whole Dutch coast line from the Belgium-Dutch border in the South to the Ems-Dollard estuary in the Northeast, including the Western Scheldt estuary and the Wadden Sea. The seaward model boundary is about $50 \mathrm{~km}$ from the coast. The cross-shore resolution of the computational flow grid increases from about $1500 \mathrm{~m}$ offshore to $75 \mathrm{~m}$ near the coast; the alongshore resolution varies between 200 and $1500 \mathrm{~m}$. The computation grid of the wave model is on average three times coarser with a cross-shore resolution between the 150 and $4000 \mathrm{~m}$ and a alongshore resolution between 150 and $4000 \mathrm{~m}$. Figures 2 show the computational grids. 


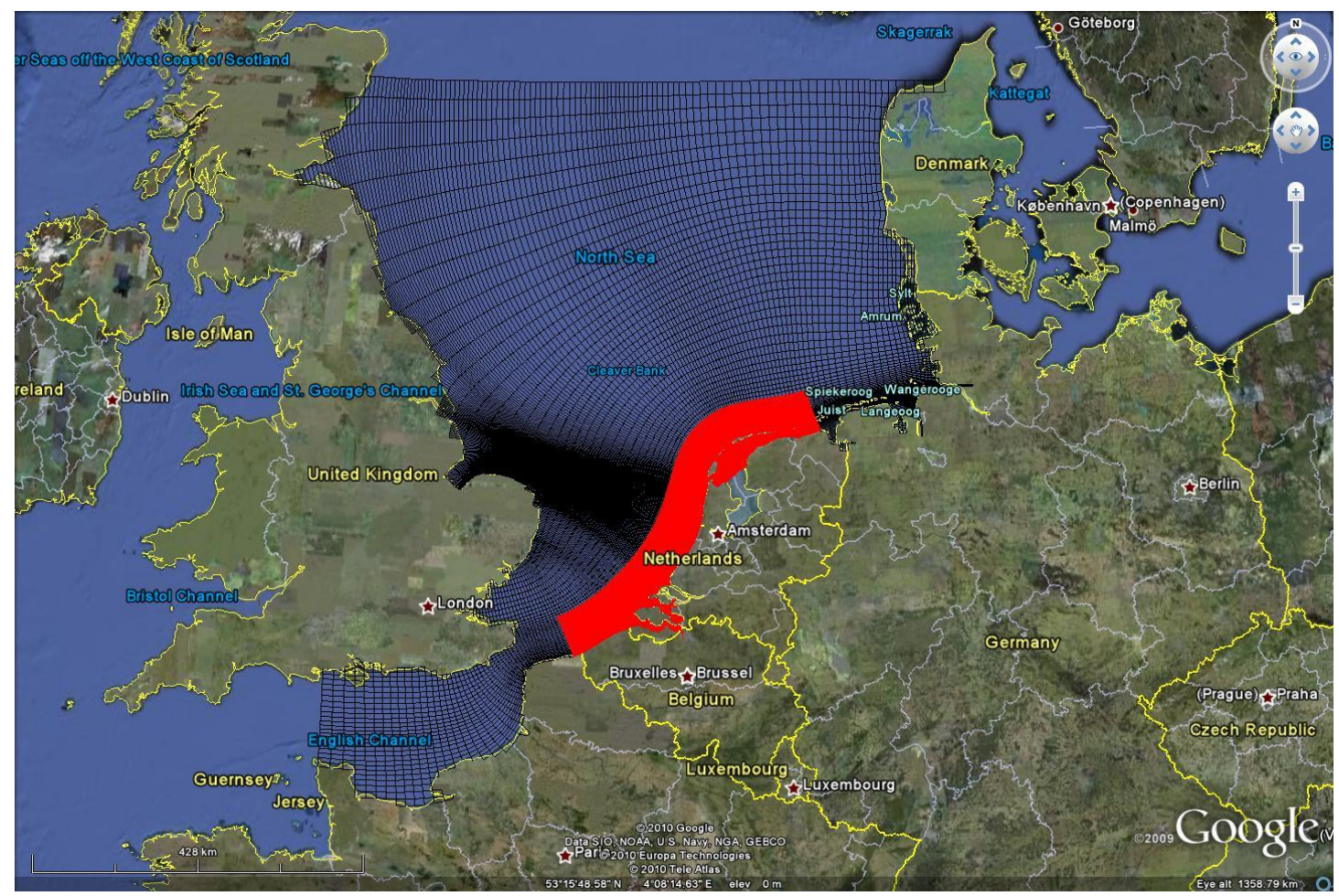

Figure 2. Computational grid ZUNO-fijn model (black lines) that was used to derive boundary conditions for the NCM model (red lines).

\section{Boundary conditions}

We impose current velocities on the lateral boundaries of the flow model and water levels on the offshore boundary. These boundary conditions are computed by the validated Delft3D model ZUNOfijn (Roelvink et al., 2001) in which the NCM model is nested. These boundary conditions have been derived for a so-called morphological tide. This is a tide that is representative for the long-term morphological development as well as the average residual sand transport rates.

Van de Rest (2004) showed that the offshore wave climate at various locations along the Dutch coasts is comparable in terms of wave height and direction. Therefore, we impose constant boundary conditions on the wave model. To derive these wave boundary conditions we use wave data measured at the station Europlatform. This station is located at relatively deep water $(32 \mathrm{~m})$ and close to the offshore boundary of the wave model. The data that are used are significant wave height $H_{1 / 3}$, significant wave period $T_{1 / 3}$, direction of wave advance $\theta_{\text {wave }}$, magnitude of wind velocity $V_{\text {wind }}$, wind direction $\theta_{\text {wind }}$ and storm surge level every 3 hours during the period from 1979 to 2001 .

The data are clustered into 10 wave heights classes from 0.0-5.0 $\mathrm{m}$ and 6 wave direction classes from $180-360^{\circ} \mathrm{N}$. Offshore waves are not taken into account. The number of conditions is reduced from 60 to 6 to reduce computational time, while ensuring that the computed morphological developments with the reduced wave climate are similar to the full wave climate. This is achieved by stepwise removing wave conditions that contribute the least to the tide-averaged longshore transport rates and re-scaling the remaining conditions such that computed transport rates are similar. Table 1 show the resulting reduced wave climate.

\begin{tabular}{|c|c|c|c|c|c|c|c|}
\hline \multicolumn{7}{|c|}{ Table 1. Reduced wave climate. } \\
\hline Condition & $\begin{array}{c}H_{1 / 3} \\
(\mathrm{~m})\end{array}$ & $\begin{array}{c}T_{1 / 3} \\
(\mathrm{~s})\end{array}$ & $\begin{array}{c}\theta_{\text {wave }} \\
\left({ }^{\circ} \mathrm{N}\right)\end{array}$ & $\begin{array}{c}\mathrm{V}_{\text {wind }} \\
(\mathrm{m} / \mathrm{s})\end{array}$ & $\begin{array}{c}\theta_{\text {wind }} \\
\left({ }^{\circ} \mathrm{N}\right)\end{array}$ & $\begin{array}{c}\text { surge level } \\
(\mathrm{m})\end{array}$ & $\begin{array}{c}\text { scaling } \\
\text { factor }\end{array}$ \\
\hline wc1 & 1.72 & 5.48 & 226 & 10.2 & 234 & 0.04 & 0.034 \\
wc2 & 1.73 & 5.67 & 284 & 8.5 & 178 & 0.19 & 0.044 \\
wc3 & 1.72 & 6.40 & 345 & 6.7 & 118 & 0.07 & 0.067 \\
wc4 & 3.23 & 6.97 & 283 & 13.5 & 165 & 0.58 & 0.150 \\
wc5 & 4.21 & 8.00 & 315 & 16.3 & 141 & 0.90 & 0.002 \\
wc6 & 4.66 & 7.94 & 234 & 20.5 & 225 & 0.10 & 0.001 \\
\hline
\end{tabular}


To assess the impact of sand extraction trenches, also three model computations have been carried out for a normative storm condition with a probability of occurrence of 1/10,000 years. Conditions are: $H_{1 / 3}=9.0 \mathrm{~m}, T_{1 / 3}=15.5 \mathrm{~s}, \theta_{\text {wave }}=330^{\circ} \mathrm{N}, V_{\text {wind }}=30 \mathrm{~m} / \mathrm{s}, \theta_{\text {wind }}=330^{\circ} \mathrm{N}$ and a storm surge level of $3.5 \mathrm{~m}$. These conditions are based on the report Hydraulische Randvoorwaarden Primaire Waterkeringen (2007) (HR, 2006) and apply to the area close to the beach town of Zandvoort.

\section{Model settings}

The time step for the flow calculations is $1 \mathrm{~min}$, and every 30 minutes the waves are computed. The bed comprises one sand fraction with a median grain size of $0.215 \mathrm{~mm}$. Bed roughness and sand transport are computed using the formulas of Van Rijn (2007a,b). Default settings were taken for most of the model parameters.

\section{Model validation}

The water levels and flow velocities computed by the NCM model are compared to the values computed by the calibrated ZUNO-fijn model. The model results agree well, indicating that the NCM model is capable of simulating the hydrodynamics in a reliable way.

Figure 3 shows the computed yearly longshore transport rates between -8 and $+3 \mathrm{~m}$ NAP from Hoek van Holland (118 km from Den Helder) to Den Helder. Positive is in the direction of Den Helder; i.e. approximately to the North. This figure shows that the longshore transport rates computed by the NCM model fall within the range of transport rates as determined in previous studies (see Van de Rest, 2004).

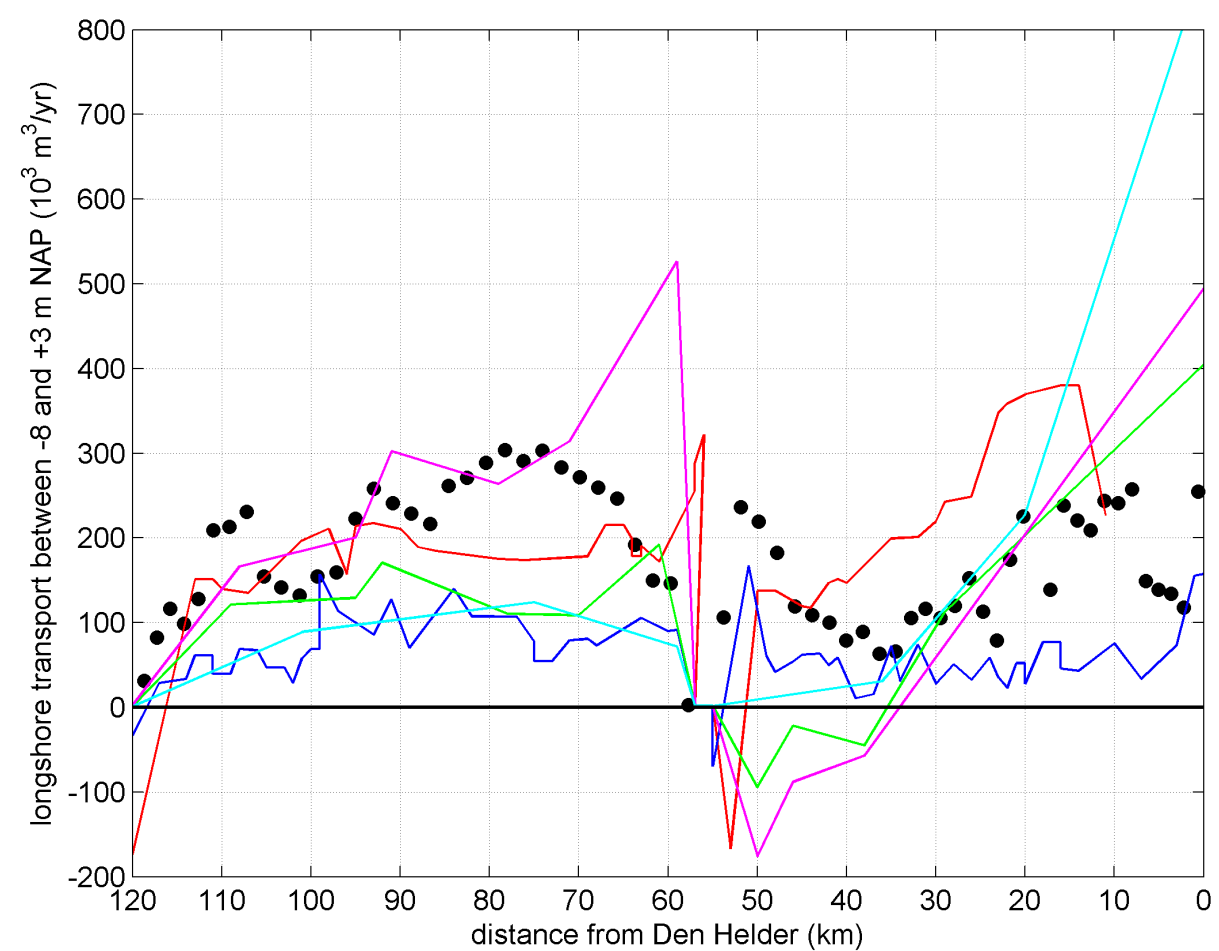

Figure 3. Yearly-averaged longshore transport rates in the surf zone along the Holland coast as computed by the NCM model (black dots) and as determined in other studies. Red line: Steetzel \& De Vroeg (1999), blue line: Roelvink et al. (2001), magenta line: Van Rijn (1995), green line: Van Rijn (1995) adjusted by Van de Rest (2004), cyan line: Stive \& Eysink (1989). See also Van de Rest (2004).

\section{Configurations sand extraction trench}

The NCM model has been used to simulate the impact of nine different sand extraction trench configurations:

1. Reference situation (i.e. without deepening)

2. Sand trench with a uniform depth of $2 \mathrm{~m}$

3. Sand trench with a uniform depth of $6 \mathrm{~m}$

4. Sand trench with a uniform depth of $12 \mathrm{~m}$ 
5. Sand trench with a non-uniform depth and with the same volume as sand trench \#3

6. Sand trench \#5 with a sand dam at the location of the narrow part of the deepening

7. Sand trench \#5 with a sand dams at latitudes corresponding to the locations of the beach towns Noordwijk, Castricum and Callantsoog

8. Sand trench \#3 without the narrow part of the deepening

9. Sand trench with a non-uniform depth and with a comparable volume as sand trench \#2

It is assumed that the deepening takes place in the area enclosed by the established NAP - $20 \mathrm{~m}$ depth contour, 12 sea miles from the coast, and (approximately) the border between Belgium and The Netherlands and between The Netherlands and Germany, respectively. In most cases, the bed levels are the result of an extreme dredging strategy. This is intentional, as then the impact on hydrodynamics and morphology is more apparent. Also, two more realistic sand extraction trenches have been simulated (\#2 and \#9), which result from compensating $1.3 \mathrm{~m}$ sea level rise in 2100 by means of increasing bed levels along the Dutch coast from about -20 to $+3 \mathrm{~m}$ NAP (the so-called coastal foundation). In cases 2, 3, 4 and 8 the deepening is spatially uniform, while the dredging volume is distributed according to the regional sand demand for cases 5, 6, 7 and 9. As a result, a "staircase" type of trench will be created with different depths in the Delta area, South-Holland, North-Holland and Wadden area (see Figure 4).

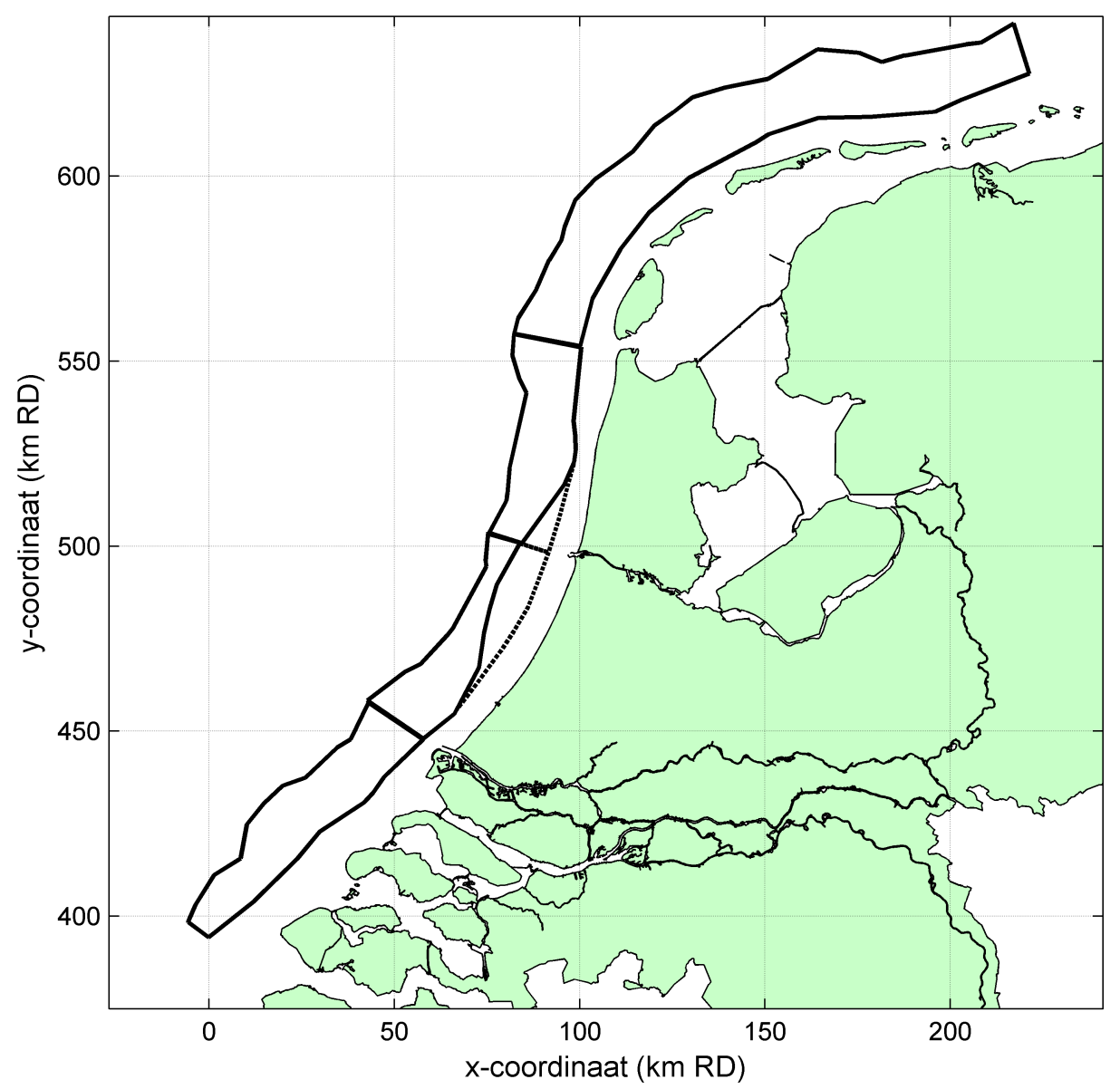

Figure 4. Contours sand extraction trench with a distinction between the Delta area, South-Holland, NorthHolland an and the Wadden area (from South-West to North-East) (solid lines). The dashed lines indicate the contours of the trench without the narrow part in the middle.

Furthermore, two sand trenches (\#6 and \#7) contain "sand dams"; an interruption of the deepening with a longshore distance of $10 \mathrm{~km}$ to represent a concentrated area with drilling rigs, windmill farms, cables and pipe lines. The narrow part of the deepening has been removed in trench 
\#8, which makes the deepening more parallel. In these cases the deepening varies between 1 and $17 \mathrm{~m}$ and the dredged volume between 10 (\#2 and \#9) and $63(\# 4) \times 10^{9} \mathrm{~m}^{3}$.

\section{MODEL RESULTS}

This sections discusses the results from the model simulations. We focus on 1 wave condition: wc6 (see Table 1). This is a $4.66 \mathrm{~m}$ high wave coming from the Southwest. The impact of the trench on waves and currents is qualitatively the same from different wave conditions. We chose the highest wave in the reduced climate as then the impact of the deepening can be most clearly observed. In the discussion below, the emphasis is on the relative impact of the deepening (i.e. compared to the reference situation, simulation \#1). For practical reasons we will only discuss the impact of the trenches with uniform depths of 2, 6 and $12 \mathrm{~m}$.

\section{Waves}

Figure 5 shows the difference in significant wave height for simulations \#4 (12 m deepening) and \#1 (reference case). The red colours indicate an increase in wave height due to the deepening, the blue colours a decrease.

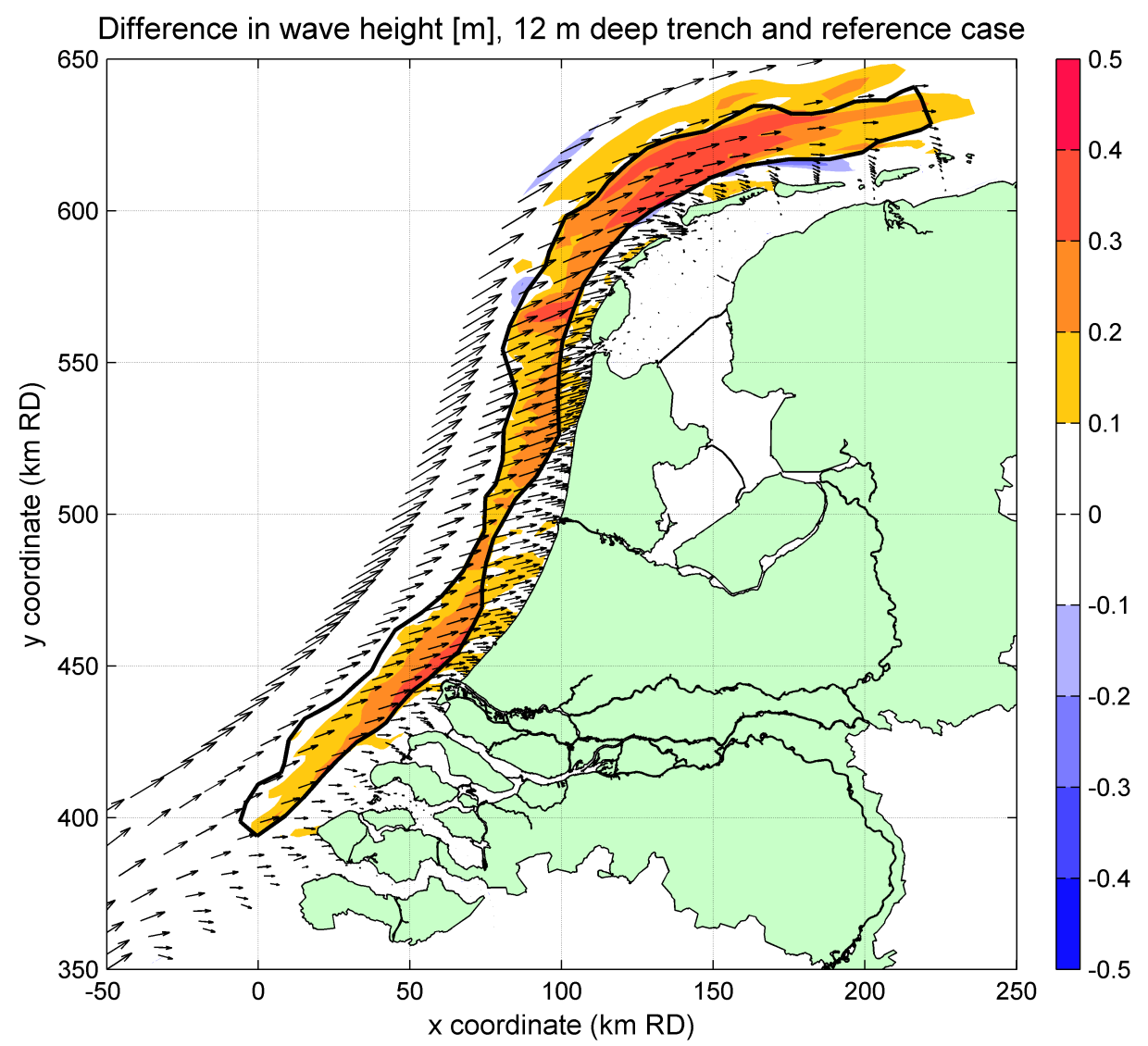

Figure 5. Difference in wave height between simulations \#4 (12 m deepening) and \#1 (reference case without deepening) for wave condition 6 . The vectors indicate the wave direction, the solid lines the contours of the sand extraction trench.

The figure shows that a very large-scale deepening along the Dutch coasts results in an increase in wave height. This is due to the fact that relatively less wave energy is dissipated due to bottom friction related to the increased water depth. The impact is strongest at the location of the trench and of lesser importance in the nearshore zone where not dissipation due to bed friction, but dissipation due to wave breaking is the dominant process. The impact is very small seaward of the deepening with the exception of the area north of the Wadden Sea. Here refraction causes an increase in wave height. In the deepened part the waves can travel faster and they therefore bend more towards the northern direction, by which wave energy is focused. This process depends on the angle of wave incidence, and will be different and/or of less importance for waves coming from the Northwest. The 
influence of the deepening increase with the depth of the trench (not shown here). The maximum wave height increase is $0.15-0.2 \mathrm{~m}$ in the trench an a few cm's near the coast for the $2 \mathrm{~m}$ deep trench (case \#2). A deepening of $6 \mathrm{~m}$ (case \#3) leads to a wave increase of $0.2-0.3 \mathrm{~m}$ in the trench; at the coast the waves are maximal $0.05-0.1 \mathrm{~m}$ higher. Finally, the deepest trench $(12 \mathrm{~m})$ leads to a maximum increase of 0.3-0.4 $\mathrm{m}$ at the deepening and 0.1-0.2 m near the coast (approx. 10\%), as can be seen in Figure 5.

\section{Currents}

The flow velocities outside the surf zone (depths larger that approx. $8 \mathrm{~m}$ ) are controlled by the tidal motion. The M2 tide with a period of $12.4 \mathrm{hrs}$ is dominant and results in more or less coast parallel flow velocity with a maximum of about $1.6 \mathrm{~m} / \mathrm{s}$ (situation without deepening).

In case of a steady flow parallel to the main axis of a elongated deepening, the flow exhibits the following behaviour (see Roos, 2004):

1. The flow accelerates just before it enters the trench due to flow contraction. The streamlines converge into the deeper part as the water can flow faster due to the reduced bed friction.

2. When the flow enters the pit, it suddenly decreases to compensate for the increased water depth (continuity of mass).

3. Subsequently, the flow gradually increases as a response to the reduced bed friction.

4. The flow velocity slowly decreases again towards the end of the deepening. Continuity of mass then generates a sudden increase in flow velocity, after which the flow velocity gradually deceases again to the undisturbed value.

Furthermore, in our case the following processes play a role:

5. Local variations in the deepening, the narrow part in particular. The narrow part results into local flow acceleration and deceleration.

6. Inertia effects. The water mass inside the trench is larger, and as such contains more inertia and responds slower to the changing water level gradient.

Figure 6 and 7 show the differences in current velocity at 12 difference tidal phase as computed for the $12 \mathrm{~m}$ depth trench (case \#4) and the reference case (\#1). The most importance observations form these figures are:

- The changes in flow velocity are maximum $0.3 \mathrm{~m} / \mathrm{s}$ or almost $20 \%$ of the peak current velocity. Near the coast, differences are much smaller; $0-0.1 \mathrm{~m} / \mathrm{s}$

- The increase in flow velocity just before entering the deepening can clearly be seen at tidal phases $\mathrm{t}=1,2$ and $3 \mathrm{hrs}$ in the Southwest and at $\mathrm{t}=8,9$ and $10 \mathrm{hrs}$ in the Northeast.

- During a large part of the tidal cycle the flow accelerates at the narrow part of the deepening. The increase in flow velocity is locally $0.2-0.3 \mathrm{~m} / \mathrm{s}$. This increase cannot be observed at $\mathrm{t}=1$ and $2 \mathrm{hrs}$ as then the local velocity is close to zero.

- Dependent on the tidal phase, velocities apparently in- or decrease in the trench as a result of the phase shift related to inertia effects.

- In general the velocities increase in the deepening due to the decreased bed friction.

Simulations \#2 and \#3 show similar effects of the deepening, but the impact is smaller as depths are smaller (not shown here). 

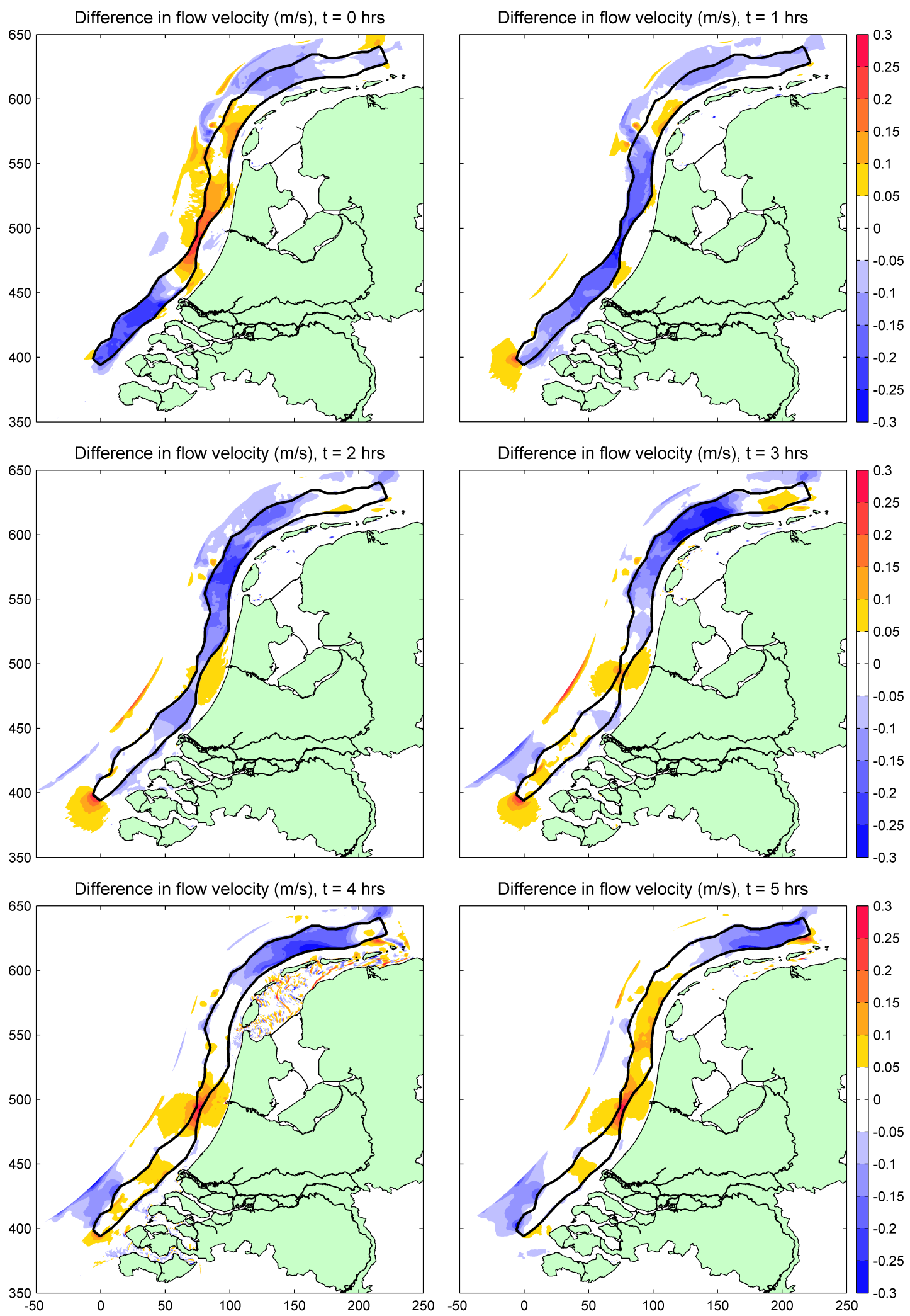

Figure 6. Difference in the magnitude of the current velocities between simulations \#4 (12 $\mathrm{m}$ deepening) and \#1 (reference case without deepening) at different tidal phases. The solid lines the contours of the sand extraction trench. 

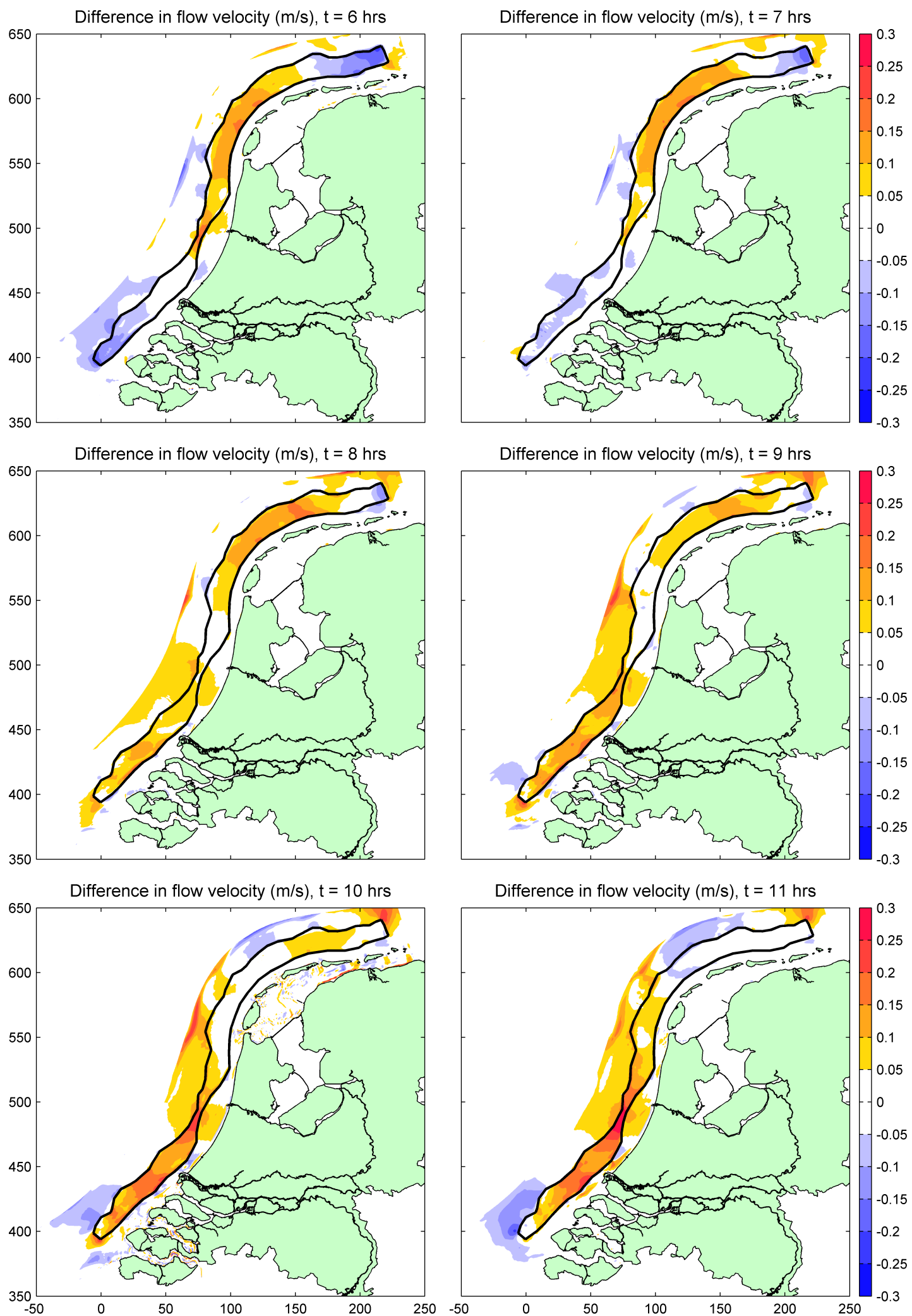

Figure 7. Difference in the magnitude of the current velocities between simulations $\$ 4$ (12 $\mathrm{m}$ deepening) and $\$ 1$ (reference case without deepening) at different tidal phases. The solid lines the contours of the sand extraction trench. 


\section{Sand transport}

Figure 8 shows the computed net yearly sand transport rates (excluding pores) through 11 crossshore and 10 alongshore transects for the reference case. The cross-shore transects run from approx. the -20 to the +3 m NAP contour. The transects enclose 10 coastal sections, from the Southeast to the Northwest: Delta (D) South and North, South-Holland (SH) South and North, North-Holland (NH) South and North, Texel-Vlieland, Vlieland-Terschelling, Terschelling-Ameland and AmelandSchiermonnikoog. The figure shows that the transport rates through the cross-shore transects are directed to the North(east), and that these transport rates are in general larger that the transport rates through the alongshore transects that are in general directed towards the coasts (accounting for the lengths of the transects).

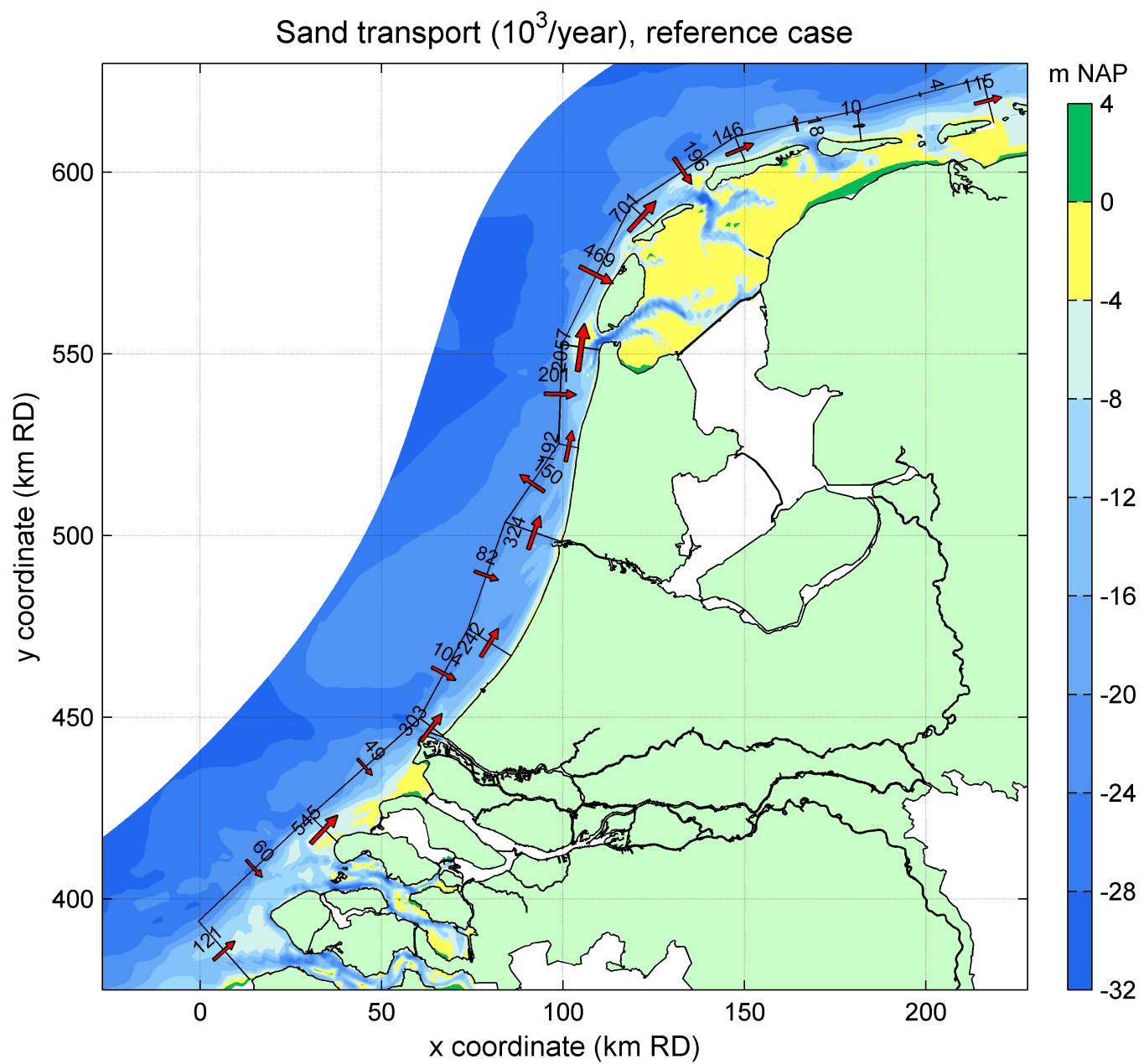

Figure 8. Tidal-averaged transport rates $\left(10^{3} \mathrm{~m}^{3} / \mathrm{year}\right)$ through various transects for simulation \#1 (reference case).

Figure 9 shows the transport rates for the $12 \mathrm{~m}$ deep trench (case \#4). The impact of the deepening can be observed by comparing the transport values with those presented in Figure 8 . The largest effect of the deepening occurs in the sections D-North, SH-South, SH-North and NH-South. This applies in particular to the transport rates through the alongshore transects. The flow contraction induced by the narrow part of the deepening results into a decrease of shoreward transport in the sections south of the narrow part (D-North and SH-South), and into a decrease of seaward transport in the sections north of the narrow part (NH-South). Comparing simulations 2, 3 and 4 shows that this effect increases with trench depth (not shown here). 


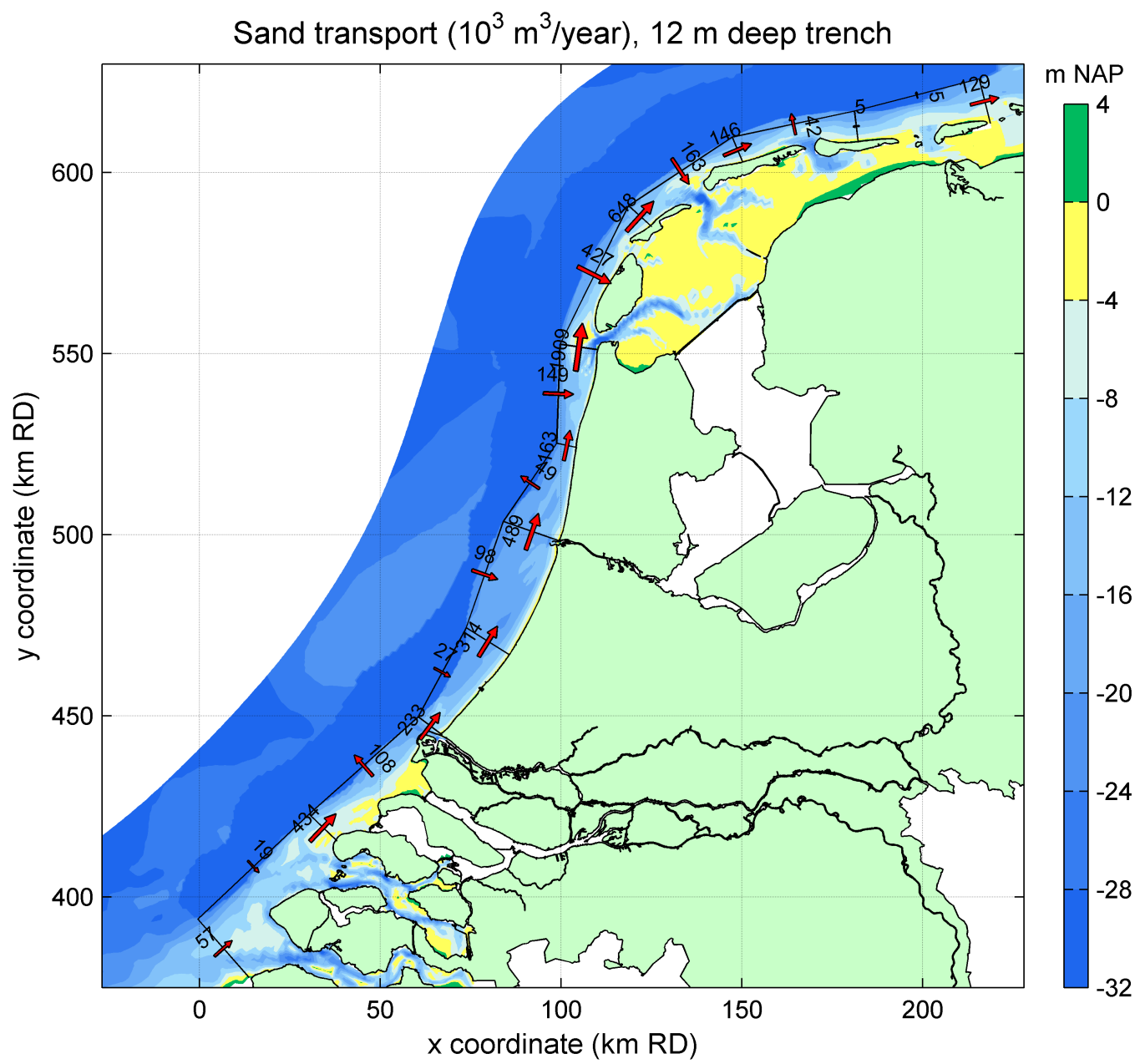

Figure 9. Tidal-averaged transport rates $\left(10^{3} \mathrm{~m}^{3} /\right.$ year) through various transects for simulation \#4 (12 $\mathrm{m}$ deepening.

\section{Morphology}

The previous sections have discussed the impact of a very large-scale sand extraction trench on the wave heights, current velocities and sand transport rates. However, it is also very interesting and relevant to know how the coastal morphology will be affected. For practical reasons, the simulations were morphostatic, i.e. bed levels were not updated. Therefore, we need study the impact of the deepening on the bed levels in an indirect way.

We are interested in two parameters: 1) the sand volume of the so-called coastal foundation and 2) the dune erosion that occurs during the normative storm condition. The coastal foundation is an important parameter in terms of safety against flooding on the long term. The coastal foundation consists of the area enclosed by the established -20 m NAP depth contour and the dunes and dikes along the coast. The dune erosion at the normative storm condition is important for the instantaneous safety against flowing.

\section{Sand volume coastal foundation}

For each coastal section (see Figures 8 and 9) we have computed the net sand import by summing the incoming and outgoing transport rates. The results for the sections South-Holland and NorthHolland are presented in Figures 10 and 11. As discussed before, the impact of the sand extraction trench is largest here. The figures show both the net sand import in $\mathrm{m}^{3} / \mathrm{year}$ as well as the change relative to the reference case. Red bars indicate sand export and relatively less sand import or more sand export. It is important to note that this analysis only provides insight in the (possible) initial change in the sand volume in the coastal foundation of the defined sections. The feedback of the morphological change on waves, currents and sand transport is not accounted for. 

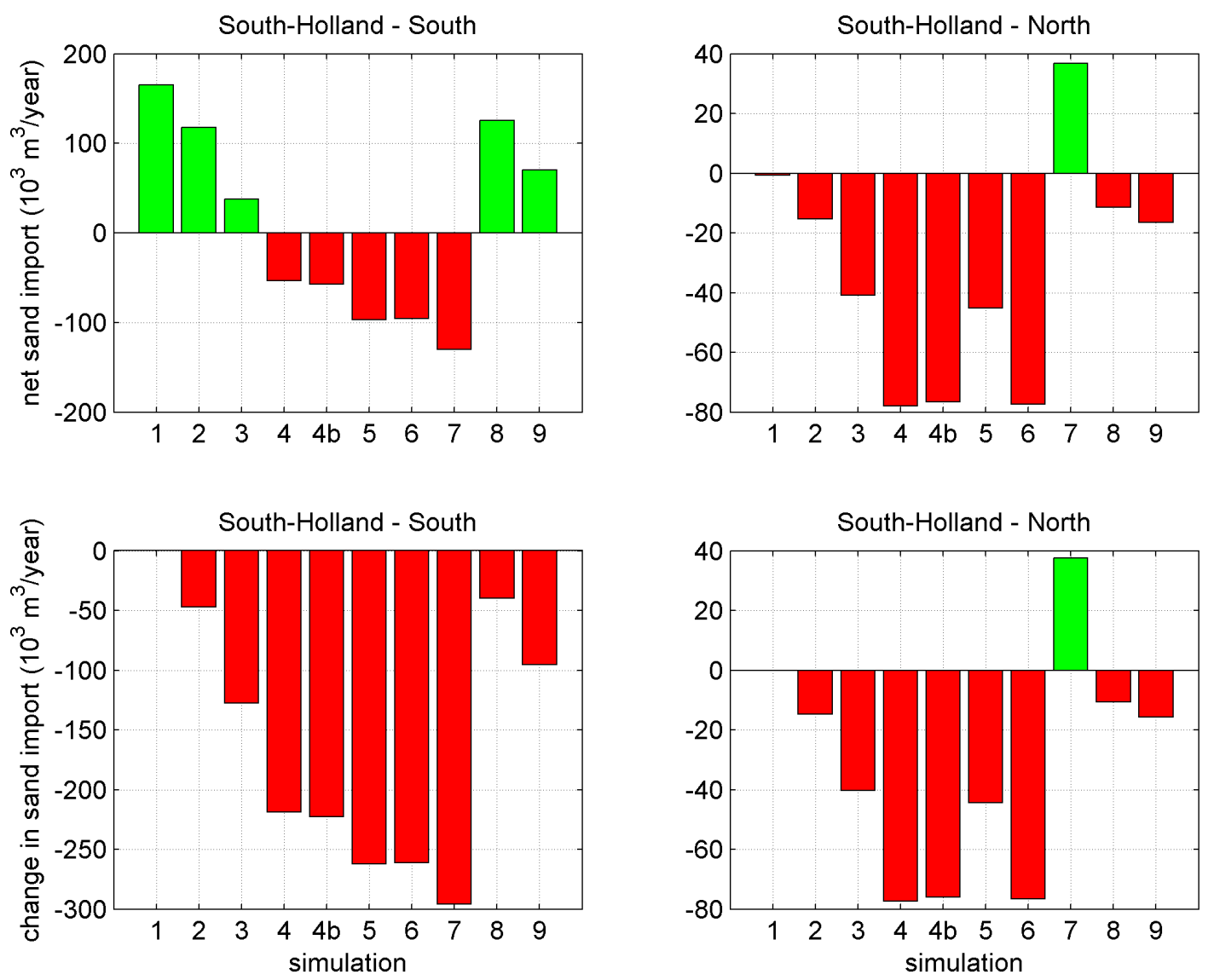

Figure 10. Net sand import for the coastal sections of South-Holland.

These figures show that the deepening results in less sand import/more sand export in the sections $\mathrm{SH}-\mathrm{South}$ and $\mathrm{SH}-\mathrm{North}$, and more sand import/less sand export for section NH-South. This is caused by flow contraction at the narrow part of the deepening due to which more water and sediment flow into the trench south of the narrow part and in the direction of the coast north of the narrow part. The impact increases with depth (compare cases 2, 3 and 4). The removal of the narrow part (simulation \#8) indeed leads to a strong decrease of the impact of deepening; the differences between the sand transport rates between simulations 8 and 1 are small.

\section{Dune erosion}

We calculate the dune erosion using the DUROS+ model (WL|Delft Hydraulics 2006). The DUROS+ model is an extension of the DUROS model with the effect of wave period on the dune erosion. The dune erosion has been determined for JARKUS transept 6400, close to the coastal town Zandvoort. We have taken a median grain size of $0.215 \mathrm{~mm}$, which corresponds to the grain size in the NCM model. As computational water level we took +5.8 m NAP, taken from HR (2006). We assume that his water level is not affected by the offshore deepening. The offshore wave boundary conditions (at $20 \mathrm{~m}$ depth) for the DUROS+ calculations follow from simulation with the NCM model (Table 2). 

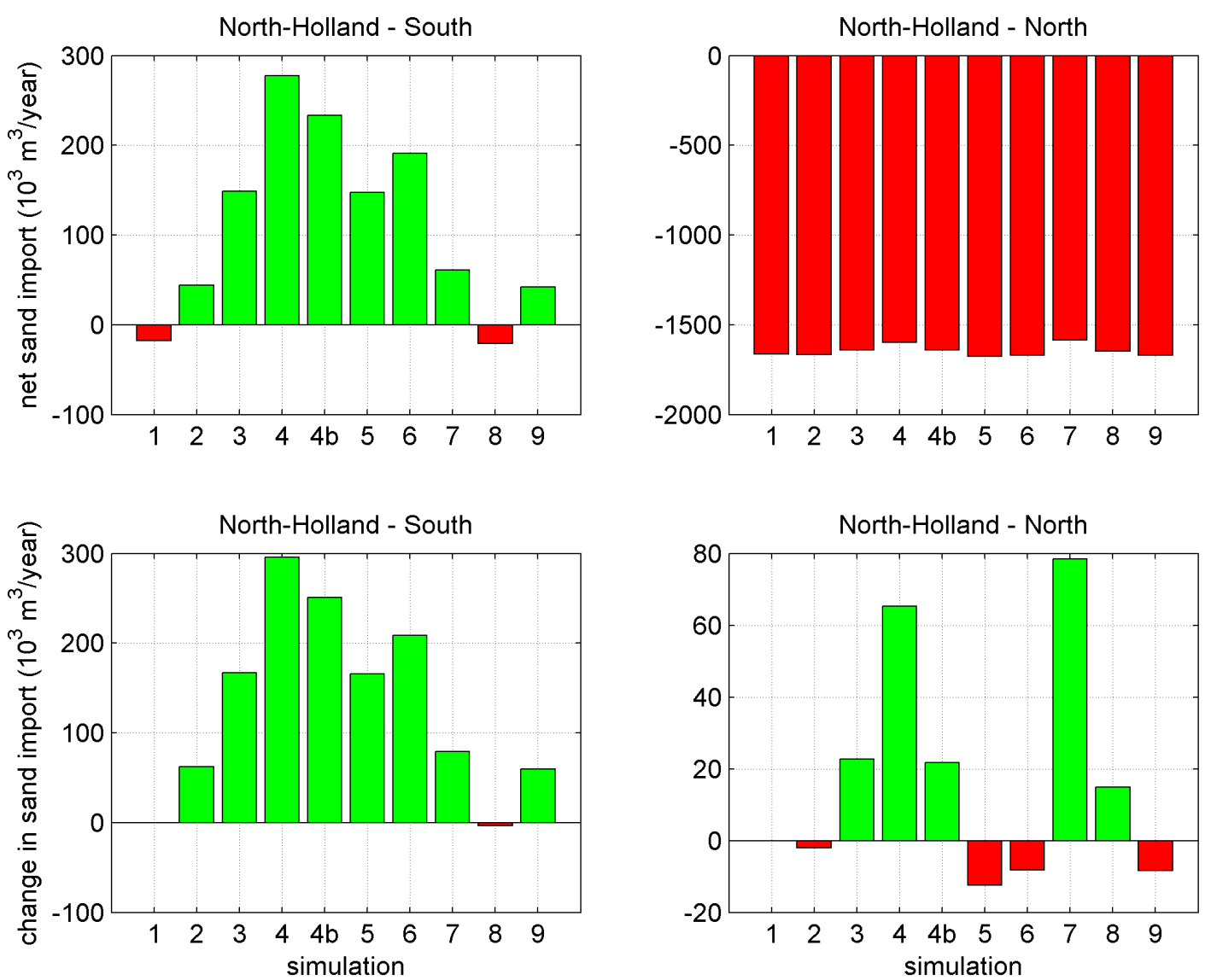

Figure 11. Net sand import for the coastal sections of North-Holland.

\begin{tabular}{|c|c|c|c|c|}
\hline \multicolumn{5}{|c|}{ Table 2. Input and output DUROS+ calculations. } \\
\hline Trench & $H_{1 / 3}(\mathrm{~m})$ & $T_{\mathrm{p}}(\mathrm{s})$ & computational level $(\mathrm{m} \mathrm{NAP})$ & dune erosion $\left(\mathrm{m}^{3} / \mathrm{m}\right)$ \\
\hline 1 & 9.00 & 15.5 & +5.8 & 520 \\
\hline 3 & 9.86 & 15.5 & +5.8 & 552 \\
\hline 4 & 9.86 & 15.6 & +5.8 & 554 \\
\hline
\end{tabular}

This table shows that the significant wave height at $20 \mathrm{~m}$ depth increases with about $10 \%$ due to the presence of the sand extraction trench. The peak wave period is hardly affected by the deepening. This table also shows that a $6 \mathrm{~m}$ deep trench (case \#3) results in a $6 \%$ increase in dune erosion due to the increase in offshore wave height. The increase is somewhat larger (7\%) for the $12 \mathrm{~m}$ deep trench (case \#4), related to the slight increase in peak period. The differences between the 6 and $12 \mathrm{~m}$ trenches are small. This suggests that an equilibrium is approached where wave height is independent on depth.

\section{CONCLUSIONS AND RECOMMENDATIONS}

In this paper we have studied the impact of various sand extraction trenches along the Dutch coast on wave heights, current velocities, sand transport rates and coastal morphology. The trenches we considered are extreme in a number of ways. First of all concerning the volume, which corresponds to 100 million $\mathrm{m}^{3}$ sand mining per year for a period of 100 years and more. Secondly, due to the way the simulations have been carried out. The bed level is fixed and the dredged sand is not put back into the coastal system, as would the case in practice where most extracted sand is meant for coastal nourishments.

The simulations show that the waves become higher due to the deepening, as bed friction is lower because the water depth is larger. This effect becomes more important for deeper trenches. The maximum increase, in case of $12 \mathrm{~m}$ deepening, is about $20 \%$ at the trench and $10 \%$ near the coast. 
The flow velocities are impacted by different processes. The decrease in bed friction leads to higher velocities inside the trench. Just outside the trench the flow velocities increase and decrease due to convergence (during inflow) and divergence (during outflow). At the edges of the trench the velocities suddenly decrease (during inflow) and increase (during outflow) as the result of mass continuity. The water mass inside the trench is larger, and as such contains more inertia, and therefore responds slower to the changing water level gradient compared to the situation without trench. Local variations in trench geometry affect the flow velocities locally as well, especially the narrow part of the sand extraction trench. At these depths $(>20 \mathrm{~m})$ waves play a minor role in the velocities. The maximum effect of the deepening on the flow velocities is $0.3 \mathrm{~m} / \mathrm{s}$ or almost $20 \%$ of the peak values. Close to the coast the impact is much smaller: $0-0.1 \mathrm{~m} / \mathrm{s}$. The influence of the trench increases with the trench depth.

The largest effect of the deepening on the integrated transport rates can be observed at the coastal sections near the narrow part of the trench (South- and North-Holland). This is especially true for the cross-shore transport rates. South of the narrow part the shoreward transport decreases; flow contraction is responsible for relatively more water and sediment flowing into the trench. North of the narrow part the opposite is true. Here, the seaward transport decreases. The integrated sand transport rates change with $20-80 \%$ for the deepest $(12 \mathrm{~m})$ trench for the coastal sections close to the narrow part, and with $10-20 \%$ for more distant sections. Again, the impact becomes larger for larger sand extraction pits.

In the simulations the bed level was kept constant. As such, we studied the impact of the deepening on coastal morphology in an indirect way. We considered two parameters that are important for coastal safety: 1) sand volume of the coastal foundation, and 2) dune erosion during normative storm condition. This analysis showed that the trench results into less sand import into the coastal section south of the narrow part of the trench and more sand import north of it. This impact is strongly reduced by removing the narrow part in the trench. Dune erosion during the normative storm condition with a frequency of occurrence of 1/10,000 year increases with $6 \%$ for the $6 \mathrm{~m}$ deep trench and with $7 \%$ for the $12 \mathrm{~m}$ deep trench. This is due to an increased wave height at $20 \mathrm{~m}$ water depth as a result of the lower bed levels. The fact that the difference between the $6 \mathrm{~m}$ and $12 \mathrm{~m}$ trench is small suggests that an equilibrium is approached where wave height is independent of depth.

This study only provided insight into the (possible) initial morphological effect of very large-scale sand mining along the Dutch coast. The simulations do not compute bed level change, and the bed level change is thus not fed back to the waves, currents and transport rates. Also, the sand is taken out instantaneously and it is not put back in the coastal foundation, as would be more realistic. Therefore, we strongly recommend carrying out a morphodynamic computation accounting for these processes.

\section{ACKNOWLEDGMENTS}

We kindly thank the Ministry of Transport, Public Works and Water Management, Rijkswaterstaat Noordzee for funding the project in which this research has been carried out.

\section{REFERENCES}

Boers, M. (2005). Effects of a deep sand extraction pit, Final report of the PUTMOR measurements at the Lowered Dump Site. Rapport RIKZ/2005.001, RIKZ, Nederland.

De Boer, W.P., P.C. Roos, S.J.M.H. Hulscher, and A. Stolk (2011). An idealized model of tidal dynamics in semi-enclosed basins: the effects of a mega-scale sand extraction in the North Sea. Proceedings Of The International Conference On Coastal Engineering, No. 32(2010), Shanghai, China. Paper \#: currents.37. Retrieved from http://journals.tdl.org/ICCE/.

HR (2006). Hydraulische Randvoorwaarden primaire waterkeringen voor de derde toetsronde 20062011. Ministerie van Verkeer en Waterstaat, Nederland.

Lesser, G.R., Roelvink, J.A., Van Kester, J.A.T.M., Stelling, G.S. (2004). Development and validation of a three dimensional morphological model. Coastal Engineering 51: 883-915.

Ribberink, J.S. (1989) Zeezandwinning, onderbouwend rapport. Rapport H0825, WL|Delft Hydraulics, Nederland.

Roelvink, J.A., Van der Kaaij, T., Ruessink, B.G. (2001). Calibration and verification of large-scale 2D/3D flow models, Phase 1. Rapport Z3029.11, WL|Delft Hydraulics/MARE, Nederland.

Roos, P.C. (2004). Seabed Pattern Dynamics and Offshore Sand Extraction. Proefschrift, Universiteit Twente, Nederland. 
Steetzel, H.J., De Vroeg, J.H, 1999. Update and validation of the PonTos-model. Rapport A244/Z2259, Alkyon Hydraulic Consultancy \& Research en WL|Delft Hydraulics, Nederland. (in het Engels)

Stive, M.J.F., Eysink, W.D., 1989. Voorspelling ontwikkeling kustlijn 1990-2090, fase 3 (deelrapport 3.1): dynamisch model van het Nederlandse kustsysteem deelrapport. Rapport H0825, WL|Delft Hydraulics, Nederland.

Van de Rest, P. 2004. Morfodynamica en hydrodynamica van de Hollandse kust. Afstudeerrapport, Technische Universiteit Delft, Nederland.

Van Rijn, L.C., Ribberink, J.S., Reniers, A., Zitman, T, 1995. Sand Budget and coastline change of the Central Dutch Coast between Den Helder and Hoek van Holland. Delft hydraulics, report H2129, Project Kustgenese.

Van Rijn, L.C. (2007a). Unified view of sediment transport by currents and waves, I: Initiation of motion, bed roughness, and bed-load transport. Journal of Hydraulic Engineering 133: 649-667.

Van Rijn, L.C. (2007b). Unified view of sediment transport by currents and waves, II: Suspended transport. Journal of Hydraulic Engineering 133: 668-689.

WL|Delft Hydraulics (2006). Dune erosion, Product 2: Large-scale model tests and dune erosion prediction, methods. Rapport H4357, WL|Delft Hydraulics, Nederland. 